\title{
Most Valuable Stakeholders: The impact of employee orientation on corporate financial performance
}

\author{
Nigel M. de Bussy, School of Marketing, Curtin University, Perth, Australia \\ and \\ Lokweetpun Suprawan, Marketing Department, Bangkok University, Thailand
}

\begin{abstract}
In sports, the Most Valuable Player award goes to the individual or group of players who have contributed most to the success of the team. This paper presents the results of two Australian empirical studies conducted six years apart, which suggest that, in business, employees are the most valuable stakeholder group. In particular, we find evidence to support the proposition that employee orientation contributes more to corporate financial performance (CFP) than orientation towards any other individual primary stakeholder group, including customers, communities, suppliers and shareholders. These findings have practical implications for corporate level strategy and the prioritization of budgetary resources by communication managers. From a theoretical perspective, the paper contributes to the debate on the best way to conceptualize employee orientation.
\end{abstract}

Keywords: Employee orientation; stakeholders; corporate financial performance

\section{Introduction}

Despite the multiplicity of definitions of the term 'stakeholder' (Mitchell, Agle, \& Wood, 1997), employees have long been regarded as primary stakeholders for most organizations (Clarkson, 1995). Hitherto, only a relatively small number of studies have attempted to evaluate the impact of adopting a stakeholder orientation on corporate financial performance and the results have been mixed (e.g., Berman, Wicks, Kotha, \& Jones, 1999; Berrone, Surroca, \& Tribó, 2007; Yau et al., 2007). Prior research on the relationship between employee orientation - one dimension of overall stakeholder orientation - and financial performance has been especially contradictory. Some studies show a positive relationship (e.g., Berman, et al., 1999; Choi \& Wang, 2009), whilst others found no direct link between the two variables (Luk, Yau, Tse, Sin, \& Chow, 2005; Zhang, 2010). Potential explanations for these inconsistencies include confusion over the nature of employee orientation, as well as the use of different methodological approaches and study settings (China versus Western countries).

The major difference in methodological approach apparent in the literature concerns the use of secondary data (in particular corporate social performance (CSP) ratings produced by an independent agency) versus surveys to collect information directly from companies. Reliance on CSP ratings is problematic on both conceptual and methodological grounds (de Bussy, 2010). One of the difficulties with equating employee orientation with Corporate Social Responsibility or CSP is that the latter concepts are broader in scope than the former. Depending on how it is defined, CSR can have both stakeholder-related and non-stakeholder related facets and these differing aspects may have contrary effects on financial performance (Hillman \& Keim, 2001). Survey research is, self-evidently, dependent on the validity of the questions asked. It appears 
some extant research may have overlooked the most basic of all forms of validity - content or face validity. In particular, the employee orientation construct has been conflated in some instances with human resource management practices, such as promotion systems and staff appraisals (Luk, et al., 2005; Zhang, 2010). There is extensive literature in the HR field examining the links between human resource management and organisational performance (Collings, Demirbag, Mellahi, \& Tatoglu, 2010). A clear distinction can be made between HR development practices and employee orientation or relations (Kuvaas, 2008).

This paper investigates two research questions. Hypotheses relating to these questions are presented later in the paper.

RQ1: What is the impact of adopting employee orientation on corporate financial performance? RQ2: How does the impact of employee orientation on corporate financial performance differ from that of orientation towards other primary stakeholder groups?

The paper proceeds as follows. We begin by explicating the nature of the employee orientation construct in the context of the broader concepts of overall stakeholder orientation (Berman, et al., 1999; de Bussy, 2010; Yau, et al., 2007) and CSR (Kim, 2010; Mishra \& Suar, 2010). We highlight the confusion over how employee orientation should be conceptualized, operationalized and measured. Next, the previously unpublished findings of a 2004 study on stakeholder orientation and financial performance specifically relating to the employee dimension of stakeholder orientation are reported. These results are compared with those of a study conducted in 2010, enabling a comparison over a six year timeframe. The 2010 employee orientation data were once again a component of a larger study, this time measuring the relationship of 'employee concern' to firm performance in comparison with other dimensions of relevance to stakeholder-focused CSR. In both cases, the data were collected from a sample of medium to large Australian companies.

\section{The employee orientation concept}

The notion of employee orientation suffers from a lack of conceptual clarity. Employee orientation has been previously conceptualized in the public relations field in terms of dialogue, encompassing the dimensions of listening, positive regard, and willingness to change (de Bussy, 2010). However, many of the extant studies on stakeholder orientation conflate the construct with CSR or CSP (e.g., Berman, et al., 1999; Ruf, Muralidhar, Brown, Janney, \& Paul, 2001; Waddock \& Graves, 1997). Other studies appear to regard employee orientation as synonymous with various human resource management practices (e.g., Luk, et al., 2005; Zhang, 2010). Those studies which equate stakeholder orientation with CSP and rely on secondary data produced by the independent CSP ratings agency KLD (e.g., Berman, et al., 1999; Choi \& Wang, 2009), are also in part operationalizing employee orientation in terms of HR/industrial relations management practices. This is because the KLD items for the employee dimension include such elements as relationships with unions, and arrangements for profit sharing and retirement benefits (Berman, et al., 1999).

It is apparent that the approach of using of CSR or CSP as a proxy for operationalizing and measuring employee orientation is potentially flawed. Hillman and Keim (2001) found that 
whilst stakeholder management leads to enhanced shareholder wealth, the use of corporate resources on non-stakeholder related social issues has a negative effect. Potentially this is one reason for many years of conflicting evidence arising from studies on the relationship between corporate social responsibility and corporate financial performance (Margolis \& Walsh, 2001). Thus, unless care is taken to isolate only stakeholder-related effects, studies which purport to measure the impact of employee orientation in terms of CSR run the risk of confounding their results by conflating stakeholder and non-stakeholder related aspects. At the other extreme, one study reached the somewhat perplexing conclusion that companies can enhance corporate social performance by disregarding their employees (Luk, et al., 2005). This finding appears to lack logical consistency. Luk et al. (2005) themselves noted earlier in their paper that 'corporate social responsibility includes the promotion of ... employee welfare,' (p. 96). We take the position that employee orientation is compatible, but not entirely synonymous, with CSR.

\section{Employee orientation and human resource management practices}

There have been many studies in the field of human resource management investigating the impact of various HR practices on firm performance (Boselie, Dietz, \& Boon, 2005; Collings, et al., 2010; Godard, 2004; Kuvaas, 2008). Typically, the practices investigated include such variables as recruitment, rewards, participation, training, opportunities for internal promotion and coaching (Paauwe \& Richardson, 1997). These are often linked to such HR outcomes as employee satisfaction, motivation, retention and loyalty which, in turn, may be associated with overall firm performance criteria including profit, market share, product quality and customer satisfaction (Paauwe \& Richardson, 1997). Boselie et al. (2005) reviewed 104 research papers on the HRM/performance relationship published between 1994 and 2003, finding many contradictions and inconsistencies as well as some commonalities. Godard (2004) found the benefits of so-called 'high-performance systems' to be over-stated, both for the firm and at the level of individual employees. 'High-performance systems' include such features as alternative work practices (e.g., work teams and quality circles) and 'high-commitment employment practices'. The latter include selection and training based on values and human relations as well as knowledge; behavior-based appraisal systems; single status policies; and, contingent pay systems (Godard, 2004). Collings et al. (2010) discussed the dichotomy in the HRM/performance literature between the 'best practice' and 'best fit' or contingency schools of thought, finding strong support for the latter in their empirical study of Turkish firms. This may help to explain the inconsistencies discovered by Boselie et al. (2005), i.e. the contradictions arise from the fact that a 'one size fits all' approach to HRM is not the most appropriate to maximizing performance in widely differing organisational and cultural contexts.

As discussed in section 1, a number of studies purporting to investigate the impact of stakeholder orientation on firm performance rely, directly or indirectly, on measures related to aspects of human resource management as a proxy for employee orientation (e.g., Berman, et al., 1999; Choi \& Wang, 2009; Luk, et al., 2005; Zhang, 2010). Even if HR management practices were an appropriate way to operationalize employee orientation, the extensive body of research in the HR discipline (largely ignored in the stakeholder and communication literatures) clearly illustrates the pitfalls of this approach. Notably, if the contingency perspective on the HRM/performance relationship is correct (Collings, et al., 2010), studies purporting to offer generalizable conclusions may be considered unreliable. However, an even more fundamental objection to this 
approach is highlighted by Kuvaas (2008), who demonstrated that HRM practices and employee orientation are, in fact, entirely separate constructs. Kuvaas (2008) tested two models, in which what he termed 'employee-organization relationship' (EOR) mediates or moderates respectively the relationship between perceived developmental HR practices and employee outcomes. It is apparent that the notion of EOR is closely aligned with what we term employee orientation. Kuvaas (2008) found that EOR plays a crucial role. A positive relationship exists between perceived HR practices and performance only when EOR is high. When EOR is low, the relationship is negative. Hence, it appears that a number of the extant studies which have attempted to measure the impact of employee orientation on performance are misdirected.

\section{Defining and operationalizing employee orientation}

\subsection{Dialogue}

Thus far, the discussion has largely focused on what employee orientation is not, i.e. the construct is not synonymous with HRM practices and refers only to the stakeholder-related dimension of CSR rather than any other facets of the latter concept. Uncontroversially, employee orientation is seen as one dimension of the broader construct of stakeholder orientation (Clarkson, 1995; de Bussy, 2010; Freeman, 1997; Yau, et al., 2007). Writing from a public relations perspective, de Bussy (2010) conceptualized stakeholder orientation (and orientation towards individual primary stakeholder groups including employees) as dialogue, operationalized in terms of the dimensions of listening, positive regard, and willingness to change. Writing almost 80 years ago, the philosopher Martin Buber contrasted dialogue with what he called the 'curious sport' of discussion (Buber, 2002: 189) - a distinction also emphasized by more recent authors (Bohm, 1990; Senge, 2006). In a discussion different views are presented and defended, whereas in dialogue different views are presented as a means towards discovering a new view (Senge, 2006). In Buber's (2002) philosophy, genuine dialogue involves each participant really having the others in mind and turning to them with the intention of establishing a living, mutual relation. Hence, the first of the two studies described in this paper defines employee orientation as an organization's inclination to engage in dialogic communication with its employees (de Bussy, 2010) and tests the following hypotheses.

$\mathrm{H}_{1}$ : Engaging in dialogic communication with employees is positively associated with corporate financial performance.

$\mathrm{H}_{2}$ : Engaging in dialogic communication with employees contributes more to corporate financial performance than dialogue with (or orientation towards) any other individual primary stakeholder group; specifically customers, suppliers, the community, and shareholders.

\subsection{Employee concern}

The second study uses a subtly different, but complementary conceptualization of employee orientation based on the notion of 'employee concern'. This construct is one of the dimensions of a new, stakeholder-focused scale of CSR branding, operationalized in terms of three facets. Firstly, a company's embedded CSR practices; secondly, its CSR-related communication; and thirdly, its CSR-related brand promises. The other dimensions of the CSR-branding construct are community commitment, environmental awareness, and financial fairness (in relation to dealings 
with customers and suppliers). As can be seen, the CSR-branding scale has been developed using a stakeholder-focused definition of corporate social responsibility (Dahlsrud, 2008), including the environment as a stakeholder in its own right (Starik, 1995). Thus, the following hypotheses have been formulated.

$\mathrm{H}_{3}$ : Employee concern is positively associated with corporate financial performance.

$\mathrm{H}_{4}$ : Employee concern contributes more to corporate financial performance than any other individual dimension of CSR branding; specifically community commitment, environmental awareness, and financial fairness.

\section{Measures and data collection}

\subsection{Study 1}

The study 1 sample frame was a comprehensive, commercially available database of Australian businesses produced by Dun and Bradstreet. Questionnaires were mailed to a sample of 1,672 chief financial officers from companies with more than 80 employees resulting in 290 responses - a response rate of $17.34 \%$. The survey was targeted at senior financial managers because they usually have a broad understanding of the status and activities of their companies, which is the unit of analysis for the research. To assess the extent of non-response bias, data from early and late respondents were compared using t-tests (Armstrong \& Overton, 1977). No significant differences were found.

The research instrument used was STAKOR - a scale designed to measure stakeholder orientation based on dialogue (de Bussy, 2010). The dependent variable (corporate financial performance) was measured using a four-item scale adapted from Maignan, Ferrell, and Hult (1999). Previous research has found a high degree of convergence between perceptual and objective measures of corporate financial performance, such as secondary data from external sources (Venkatraman \& Ramanujam, 1987). The four items in the CFP scale asked respondents about various financial performance indicators (e.g., return on investment, sales growth) over the previous three years, relative to their competitors. Shareholder orientation, which does not form part of the STAKOR scale (de Bussy, 2010), was measured using a specially developed threeitem scale comprising the following items. The emphasis in this organization is on maximizing shareholder value over the long term; The focus of this organization is to maximize the present value of future cash flow for its owners; and, Management in this organization goes to great lengths to meet shareholder expectations. All items were measured with 7-point Likert scales, anchored by strongly agree (7) and strongly disagree (1). Following confirmatory factor analysis using AMOS 18, composite scales were computed using the factor scores for each item (Arbuckle, 1997). This method takes into account the weighting of each individual indicator of the construct of interest, as well as the indicators' individual and joint measurement error. Descriptive statistics, construct reliability and variance extracted scores for each construct are provided in Table 1. All values exceed the accepted standards (Hair, Anderson, Tathan, \& Black, 1995), with the exception of the variance extracted for shareholder orientation which falls marginally below .5 . 
Insert Table 1 about here

\subsection{Study 2}

The commercially available ORBIS database was used as the sample frame for study 2. A total of 2,732 questionnaires were distributed to CEOs and marketing managers, depending on the data available in the database. Marketing managers were selected wherever possible, given the likelihood they would be in a position to comment on their organization's branding practices. Unfortunately, public relations/corporate communication managers are not identifiable in the ORBIS database. A total of 201 questionnaires were returned; a response rate of $7.36 \%$. The low response rate in comparison with study 1 reflects the long-standing trend of declining response rates in many kinds of survey research (Tourangeau, 2004). However, non-response bias was again investigated by comparing the data from early and late respondents (Armstrong \& Overton, 1977). With the minor exception of one item relating to corporate financial performance, no significant differences were found. Thus, it is reasonable to assume that non-response bias does not present a problem in interpreting the results. The response rate is similar to a number of other comparable recent studies (e.g., Singhapakdi, Sirgy, \& Lee, 2010; Singhapakdi \& Vitell, 2007).

The four dimensions of CSR branding were measured with a newly developed 17-item scale, comprising four items each for employee concern, community commitment, and financial fairness, in addition to five items for environmental awareness. The items relating to employee concern were as follows: Our organization presents itself as a caring employer; Our organization has made a clear promise to be a caring employer; Achieving work/life balance for employees is of central importance to our organization; and, Providing employees with opportunities for personal development is considered of central importance to our organization even if it does not directly benefit the business. Corporate financial performance was measured using the same four-item scale as in study 1 (Maignan, et al., 1999). All items were measured with 7-point Likert scales, anchored by strongly agree (7) and strongly disagree (1). As in study 1 , confirmatory factor analysis using AMOS 18 was followed by the creation of composite scales using the factor scores for each item (Arbuckle, 1997). Descriptive statistics, construct reliability and variance extracted scores for each construct are provided in Table 2. All values exceed the accepted standards (Hair, et al., 1995), with the exception of variance extracted for financial fairness, community commitment, and overall CSR branding. Given that the composite reliability for these constructs exceeded .7 and convergent validity was also demonstrated by significant regression weights in the confirmatory factor analysis, it appeared reasonable to continue model testing.

Insert Table 2 about here 


\section{Results}

\subsection{Study 1}

Before proceeding with the analysis, 56 cases were deleted because they did not identify themselves as operating in the 'for profit' sector. This left a sample of 234 commerciallyoriented enterprises which was used in subsequent analysis. It has been suggested that 200 is, in general, an acceptable sample size for structural equation modeling (Hoelter, 1983). The rationale for this approach was that the hypotheses to be tested involved comparing employee orientation and that of other primary, non-financial stakeholder groups with shareholder orientation. Clearly, shareholder orientation is not applicable to non-profit organizations. Of the remaining 234 respondents, 85.9\% were male with a mean of 9.95 years service with their current organizations. Some $88 \%$ of respondents held tertiary qualifications. The modal age range was $45-54$ years (33.9\%), followed by 35-44 years (31.8\%). The median number of employees in respondents’ companies was 125.

Hypotheses 1 and 2 were tested simultaneously with structural equation modeling using AMOS 18. The error terms for customer orientation and both community orientation and shareholder orientation were allowed to covary. This respecification of the model was made following inspection of the modification indices. It is apparent that the model is an excellent fit with the data, as illustrated in Table 3. Table 4 provides the standardized regression weights for each relationship in the model. In the measurement model, stakeholder orientation and shareholder orientation together account for $14 \%$ of the variance in corporate financial performance. However, the regression weight for stakeholder orientation (.28) is considerably higher than that for shareholder orientation (.18). In other words, although both orientations contribute to financial performance, stakeholder orientation is the more important of the two - despite the fact that the difference is offset somewhat by the modest contribution shareholder orientation makes to stakeholder orientation. Of the primary stakeholder group orientations contributing to overall stakeholder orientation, employee orientation is the most important by a considerable margin $\left(\mathrm{R}^{2}\right.$ .65). Supplier orientation $\left(\mathrm{R}^{2} .48\right)$, customer orientation $\left(\mathrm{R}^{2} .46\right)$ and community orientation $\left(\mathrm{R}^{2}\right.$ .40) appear to be of approximately equal importance behind employee orientation. Since this model does not enable a direct comparison to be made between employee orientation in isolation and shareholder orientation, separate regression analyses were conducted to assess the impact of these two orientations respectively on financial performance. The $\mathrm{R}^{2}$ statistic for employee orientation was .09, compared with .07 for shareholder orientation. In both analyses, the regression coefficients were significant at the $p \leq .001$ level. Hence both Hypotheses 1 and 2 are supported. Engaging in dialogic communication with employees is positively associated with corporate financial performance and contributes more to financial performance than dialogue with (or orientation towards) any other individual primary stakeholder group; specifically, shareholders, customers, suppliers and the community. 
Insert Table 3 about here

Insert Table 4 about here

\subsection{Study 2}

Of the 201 respondents in study 2, 79.4\% were male with a mean of 10.36 years service with their current organizations. Some $89.4 \%$ of respondents held tertiary qualifications. The modal age range was $45-54$ years (38.5\%), followed by $35-44$ years (26.5\%) and 55 years or over (25.5\%). The median number of employees in respondents' companies was 300 . The CEO or managing director personally completed the survey in $34.4 \%$ of cases, with $26.7 \%$ of respondents in the position of marketing manager. The remaining respondents reported a variety of job titles including general manager, business development manager, CSR/sustainability officer, and communication officer. Hypotheses 3 and 4 were tested simultaneously with structural equation modeling using AMOS 18. The error terms for two indicators of corporate financial performance were allowed to covary. This respecification of the model was made following inspection of the modification indices. It is apparent that the model is a good fit with the data, as illustrated in Table 5. Table 6 provides the standardized regression weights for each relationship in the model. In the measurement model, CSR branding accounts for $20 \%$ of the variance in corporate financial performance. Of the dimensions of CSR branding, employee concern is the most important ( $\left.R^{2} .58\right)$, followed by financial fairness $\left(R^{2} .47\right)$, environmental awareness $\left(\mathrm{R}^{2} .35\right)$ and community commitment $\left(\mathrm{R}^{2} .29\right)$. Hence both Hypotheses 3 and 4 are supported. Employee concern is positively associated with corporate financial performance and contributes more to financial performance than any other individual dimension of CSR branding; specifically, financial fairness, environmental awareness and community commitment.

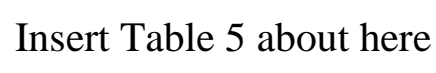

Insert Table 6 about here

\section{Discussion}

\subsection{Theoretical implications}

The main theoretical contribution of this paper lies in clarifying the nature of the employee orientation construct. As discussed, the concept has frequently been conflated in the extant literature with both CSP (e.g., Berman, et al., 1999; Choi \& Wang, 2009) and various human 
resource management practices (e.g., Luk, et al., 2005; Zhang, 2010). We acknowledge that there is not necessarily only one way to conceptualize employee orientation, indeed a comparison of the two studies presented in this paper demonstrates this is the case. However, we contend that there are fundamental criteria involved which all proposed conceptualizations should meet. Crucially, employee orientation is about the spirit in which organizations engage with their employees - not about specific communication or human resource management techniques (de Bussy, Ewing, \& Pitt, 2003). The HR literature suggests that the effectiveness of various human resource management practices may well be contingent on specific organisational and cultural contexts (Collings, et al., 2010), including the nature of the employee/organization relationship (Kuvaas, 2008). The 'best practice' paradigm may be inappropriate in this regard. In contrast, we claim that employee orientation is of universal value - although, as discussed in section 8 , we recognize the need for additional research in cross-cultural contexts to fully demonstrate this.

The true nature of employee orientation is eloquently captured in the writings of Martin Buber on the characteristics of genuine dialogue. As mentioned in section 4.1, this involves each participant really having the others in mind and turning to them with the intention of establishing a living, mutual relation (Buber, 2002). Such an approach is compatible with the notions of Kantian ethics, which have been used as a framework in previous stakeholder theory scholarship (Evan \& Freeman, 1988). Kant's second formulation of the categorical imperative is, 'One ought to treat others as having intrinsic value in themselves, and not [emphasis in the original] merely as means to achieve one's end' (Donaldson \& Werhane, 1988, p. 13). This is typically interpreted to mean one should respect every person as a rational and free being (Donaldson \& Werhane, 1988). In their article on stakeholder theory and 'Kantian capitalism', Evan and Freeman (1988) argued no stakeholder may be used as a means to the ends of another without having the right to participate fully in the relevant decision. Later Freeman (1997) elaborated on the same basic position, using principles of contractual fairness derived from the modern deontological philosopher John Rawls. We contend the two versions of employee orientation presented in this paper - employee dialogue and employee concern - are consistent with the above considerations. These two constructs are also consistent with stakeholder-focused conceptualizations of CSR (Dahlsrud, 2008). However, they should not be confused with perspectives of CSR which take an alternative (usually broader) approach, such as those incorporating social issue participation (Hillman \& Keim, 2001).

\subsection{Managerial implications}

The results of both studies presented in this paper suggest that managers interested in maximizing the financial performance of their companies should pay careful attention to the quality of their relationships with primary stakeholder groups - in particular their employees. It will be recalled that in study 1, orientation towards employees, customers, suppliers, communities and shareholders in combination accounted for $14 \%$ of the variance in corporate financial performance. In study 2, CSR branding (comprising four stakeholder-related dimensions associated with employees, customers/suppliers, communities and the natural environment) accounted for $20 \%$ of the variance in CFP. These are non-trivial results suggesting, other things being equal, that companies which do pay attention to their stakeholder relationships can expect to be considerably more profitable over the medium term than rivals who do not. As discussed above, in both studies employee orientation made the single biggest contribution to the 
results. Since employee orientation is about genuine dialogue and relationships between the organization and its employees, it follows that the public relations/communication management function is the most appropriate area to facilitate organisational efforts in this regard - not human resource management whose focus lies elsewhere (Kuvaas, 2008).

Given that the two studies investigated somewhat different aspects of the same broad area of organisational behavior, an examination of the respective descriptive statistics is illuminating (see Tables 1 and 2). The results for study 1 reveal the stakeholder priorities for the typical organisational respondent. Shareholders come first, followed by customers, employees, suppliers and the community in that order. To maximize financial performance, managers would be well advised to reconsider those priorities by boosting employees to first position. The results of study 1 show that CFP is maximized by engaging in dialogical communication with non-financial stakeholders (especially employees), whilst maintaining a concurrent focus on shareholder value. In study 2, respondents reported on their organizations' behavior with respect to stakeholderrelated CSR. The relevant descriptive statistics (see Table 2) again provide insights into current managerial priorities. In a CSR context, companies prioritize their employees first, fair dealings with customers and suppliers second, followed by commitment to the community and environmental responsibility in that order. If the goal of corporate CSR programs is at least in part strategic (i.e., the desire to 'do well by doing good'), then Australian companies appear on average to have their stakeholder-related CSR priorities about right.

\section{Limitations and recommendations for future research}

The most obvious limitation of this paper gives rise directly to the most important recommendation for future research. Despite the fact that the findings of the two studies conducted six years apart reinforce each other, it remains the case that they relate to a single country (Australia). Given the proposition put forward in section 7.1, that employee orientation (and stakeholder orientation in general) is potentially of universal benefit to business organizations, it is necessary to replicate this research in other countries. In particular, additional research should be conducted in non-Western countries and/or developing economies to find out if these results really are transferable to different socio-political and cultural settings. Another limitation of this research is the relatively low response rate, particularly in study 2. Although tests for non-response bias did not suggest any problems (Armstrong \& Overton, 1977), a higher response rate would nevertheless have been preferable. Finally, future research could shed further light on the issues discussed in this paper by using qualitative and/or mixed-method approaches. In particular, a case study method could be especially fruitful for examining in richer detail the approaches of different companies to employee orientation and the consequences for financial performance.

\section{Conclusion}

This paper set out to investigate two research questions: What is the impact of adopting employee orientation on corporate financial performance? And, how does the impact of employee orientation on corporate financial performance differ from that of orientation towards other primary stakeholder groups? Based on two empirical studies of medium to large Australian companies undertaken six years apart, answers to those questions may now be proposed. 
Employee orientation makes a strong contribution to corporate financial performance and its impact in this regard is greater than that of orientation towards any other individual primary stakeholder group, including shareholders, customers, suppliers, the community and the natural environment. Employees, it appears, are indeed the Most Valuable Stakeholders in business organizations.

\section{References}

Arbuckle, J. L. (1997). Amos users' guide version 3.6. Chicago: SmallWaters Corporation. Armstrong, J., \& Overton, T. (1977). Estimating nonresponse bias in mail surveys. Journal of Marketing Research, 14(3), 396-402.

Berman, S. L., Wicks, A. C., Kotha, S., \& Jones, T. M. (1999). Does stakeholder orientation matter? The relationship between stakeholder management models and firm financial performance. Academy of Management Journal, 42(5), 488-506.

Berrone, P., Surroca, J., \& Tribó, J. A. (2007). Corporate ethical identity as a determinant of firm performance: A test of the mediating role of stakeholder satisfaction. Journal of Business Ethics, 76, 35-53.

Bohm, D. (1990). On dialogue. Ojal, CA: David Bohm Seminars.

Boselie, P., Dietz, G., \& Boon, C. (2005). Commonalities and contradictions in HRM and performance research. Human Resource Management Journal, 15(3), 67-94.

Buber, M. (2002). From "Dialogue" (1932). In A. D. Biemann (Ed.), The Martin Buber reader (pp. 189-205). New York, NY: Palgrave MacMillan.

Choi, J., \& Wang, H. (2009). Stakeholder relations and the persistence of corporate financial performance. Strategic Management Journal, 30, 895-907.

Clarkson, M. B. E. (1995). A stakeholder framework for analyzing and evaluating corporate social performance. Academy of Management Review, 20(1), 92-117.

Collings, D. G., Demirbag, M., Mellahi, K., \& Tatoglu, E. (2010). Strategic orientation, human resource management practices and organizational outcomes: Evidence from Turkey. The International Journal of Human Resource Management, 21(14), 2589-2613.

Dahlsrud, A. (2008). How corporate social responsibility is defined: An analysis of 37 definitions. Corporate Social Responsibility and Environmental Management, 15(1), 113.

de Bussy, N. M. (2010). Dialogue as a basis for stakeholder engagement: Defining and measuring the core competencies. In R. L. Heath (Ed.), The Sage Handbook of Public Relations (2nd ed., pp. 127-144). Thousand Oaks, CA: Sage.

de Bussy, N. M., Ewing, M. T., \& Pitt, L. F. (2003). Stakeholder theory and internal marketing communication: A framework for analysing the influence of new media. Journal of Marketing Communications, 9(3), 147-161.

Donaldson, T., \& Werhane, P. H. (Eds.). (1988). Ethical issues in business: A philosophical approach (4th ed.). Englewood Cliffs, NJ: Prentice Hall.

Evan, W. M., \& Freeman, R. E. (1988). A stakeholder theory of the modern corporation: Kantian capitalism. In T. L. Beauchamp \& N. E. Bowie (Eds.), Ethical theory and business (3rd ed., pp. 97-106). Englewood Cliffs, NJ: Prentice Hall.

Freeman, R. E. (1997). A stakeholder theory of the modern corporation. In T. L. Beauchamp \& N. E. Bowie (Eds.), Ethical theory and business (5th ed., pp. 66-76). Upper Saddle River, NJ: Prentice Hall. 
Godard, J. (2004). A critical assessment of the high-performance paradigm. British Journal of Industrial Relations, 42(2), 349-378.

Hair, J. F., Anderson, R. E., Tathan, R. L., \& Black, W. C. (1995). Multivariate data analysis (4th. ed.). Upper Saddle River, NJ: Prentice Hall.

Hillman, A. J., \& Keim, G. D. (2001). Shareholder value, stakeholder management, and social issues: What's the bottom line? Strategic Management Journal, 22(2), 125-139.

Hoelter, J. (1983). The analysis of covariance structures: Goodness-of-fit indices. Sociological Methods and Research, 11(3), 325-344.

Kim, J.-W. (2010). Assessing the long-term financial performance of ethical companies. Journal of Targeting, Measurement and Analysis for Marketing, 18(3/4), 199-208.

Kuvaas, B. (2008). An exploration of how the employee-organization relationship affects the linkage between perception of developmental human resource practices and employee outcomes. Journal of Management Studies, 45(1), 1-25.

Luk, C., Yau, O. H., Tse, A. C., Sin, L. Y., \& Chow, R. P. (2005). Stakeholder orientation and business performance: The case of service companies in China. Journal of International Marketing, 13(1), 89-110.

Maignan, I., Ferrell, O. C., \& Hult, G. T. M. (1999). Corporate citizenship: Cultural antecedents and business benefits. Journal of the Academy of Marketing Science, 27(4), 455-469.

Margolis, J. D., \& Walsh, J. P. (2001). People and profits? The search for a link between a company's social and financial performance. Hillsdale, NJ: Lawrence Erlbaum Associates.

Mishra, S., \& Suar, D. (2010). Does corporate social responsibility influence firm performance of Indian companies? Journal of Business Ethics, 95, 571-601.

Mitchell, R. K., Agle, B. R., \& Wood, D. J. (1997). Toward a theory of stakeholder identification and salience: Defining the principle of who and what really counts. Academy of Management Review, 22(4), 853-886.

Paauwe, J., \& Richardson, R. (1997). Introduction special issue on HRM and performance. International Journal of Human Resource Management, 8(3), 257-262.

Ruf, B. M., Muralidhar, K., Brown, R. M., Janney, J. J., \& Paul, K. (2001). An empirical investigation of the relationship between change in corporate social performance and financial performance: A stakeholder theory perspective. Journal of Business Ethics, 32, 143-156.

Senge, P. M. (2006). The fifth discipline (2nd ed.). London: Random House.

Singhapakdi, A., Sirgy, M. J., \& Lee, D.-J. (2010). Is small business better than big business for marketing managers? Journal of Business Research, 63, 418-423.

Singhapakdi, A., \& Vitell, S. J. (2007). Institutionalization of ethics and its consequences: A survey of marketing professionals. Journal of the Academy of Marketing Science, 35, 284-294.

Starik, M. (1995). Should trees have managerial standing? Toward stakeholder status for nonhuman nature. Journal of Business Ethics, 14(3), 207-217.

Tourangeau, R. (2004). Survey research and societal change. Annual Review of Psychology, 55, 775-801.

Venkatraman, N., \& Ramanujam, V. (1987). Measurement of business economic performance: An examination of method convergence. Journal of Management, 13(1), 109-122.

Waddock, S. A., \& Graves, S. B. (1997). The corporate social performance-financial performance link. Strategic Management Journal, 18(4), 303-319. 
Yau, O. H., Chow, R. P., Sin, L. Y., Tse, A. C., Luk, C., \& Lee, J. S. (2007). Developing a scale for stakeholder orientation. European Journal of Marketing, 41(11/12), 1306-1327.

Zhang, J. (2010). Employee orientation and performance: An exploration of the mediating role of customer orientation. Journal of Business Ethics, 91, 111-121.

Table 1

Study 1 Construct Descriptive Statistics, Composite Reliabilities and Variance Extracted.

\begin{tabular}{lllll}
\hline Construct & Mean & SD & CR & VE \\
\hline Employee Orientation & 5.26 & 1.02 & .898 & .638 \\
Community Orientation & 4.44 & 1.33 & .903 & .701 \\
Supplier Orientation & 5.04 & 1.04 & .855 & .599 \\
Customer Orientation & 5.42 & 0.93 & .807 & .518 \\
Overall Stakeholder Orientation & 5.12 & 0.83 & .800 & .501 \\
Shareholder Orientation & 5.45 & 1.05 & .723 & .476 \\
Corporate Financial Performance & 4.56 & 1.52 & .845 & .590 \\
\hline
\end{tabular}

Table 2

Study 2 Construct Descriptive Statistics, Composite Reliabilities and Variance Extracted.

\begin{tabular}{lllll}
\hline Construct & Mean & SD & CR & VE \\
\hline Employee Concern & 5.33 & 1.02 & .819 & .531 \\
Community Commitment & 4.81 & 1.37 & .738 & .429 \\
Environmental Awareness & 4.48 & 1.38 & .868 & .572 \\
Financial Fairness & 5.11 & .972 & .711 & .386 \\
Overall CSR Branding & 5.05 & .850 & .745 & .426 \\
Corporate Financial Performance & 4.77 & 1.47 & .874 & .646 \\
\hline
\end{tabular}

Table 3

Study 1 Selected Model Fit Statistics.

\begin{tabular}{lllllll}
\hline $\boldsymbol{p}$ & CMIN/DF & RMR & GFI & AGFI & NFI & TLI \\
\hline .695 & .644 & .025 & .995 & .981 & .988 & 1.017 \\
\hline
\end{tabular}

Table 4

Study 1 Standardized regression weights.

\begin{tabular}{|c|c|}
\hline & Estimate \\
\hline Shareholder Orientation $\leftarrow$ Stakeholder Orientation & .291 \\
\hline Employee Orientation $\leftarrow$ Stakeholder Orientation & .809 \\
\hline Community Orientation $\leftarrow$ Stakeholder Orientation & .632 \\
\hline Supplier Orientation $\leftarrow$ Stakeholder Orientation & .694 \\
\hline Customer Orientation $\leftarrow$ Stakeholder Orientation & .681 \\
\hline Corporate Financial Performance $\leftarrow$ Shareholder Orientation & .185 \\
\hline Corporate Financial Performance $\leftarrow$ Stakeholder Orientation & .283 \\
\hline
\end{tabular}


Table 5

Study 2 Selected Model Fit Statistics.

\begin{tabular}{lllllll}
\hline $\boldsymbol{p}$ & CMIN/DF & RMR & GFI & AGFI & NFI & TLI \\
\hline .486 & .975 & .077 & .979 & .958 & .980 & 1.001 \\
\hline
\end{tabular}

Table 6

Study 2 Standardized regression weights.

\begin{tabular}{|c|c|}
\hline & Estimate \\
\hline Corporate Financial Performance $\leftarrow$ CSR Branding & .442 \\
\hline Environmental Awareness $\leftarrow$ CSR Branding & .593 \\
\hline Community Commitment $\leftarrow$ CSR Branding & .536 \\
\hline Employee Concern $\leftarrow$ CSR Branding & .765 \\
\hline Financial Fairness $\leftarrow$ CSR Branding & .685 \\
\hline
\end{tabular}

